\title{
The Analysis of Port Integration on Fishing Cold Chain: The Case of Collaboration Between General Port and Fish Operator
}

\author{
Eko Hariyadi Budiyanto ${ }^{a, *}$, Raja Oloan Saut Gurningb and Danang Cahyagi ${ }^{\mathrm{c}}$ \\ ${ }^{1}$ Department of Marine Engineering, Institut Teknologi Sepuluh Nopember, Indonesia \\ a.ehaydi@teluklamong.co.id, b.sautg@its.ac.id,c.cahyagil6@mhs.ne.its.ac.id \\ *corresponding author
}

Keywords: $\quad$ port integration; fishing cold chain; port collaboration; operational model.

\begin{abstract}
The development of fishery sector in Indonesia, especially in the north coast of Java has led to a more intensive fishery product flow. The development consists of both domestic and export demand. As consequences, product quality, environment, transportation, cold chain system, and ports should bring as the basis that must be strengthened to create sustainable fisheries. In general, Indonesia fishing port has a separate system from a general port that deals with cargoes. Although in practice (especially in the Port of Tegal), fishing boats also berthing, drop off, and trade at general ports area. The disadvantage that very clearly felt by the fishermen are the lack of development of cold chain system that impact on fishery products and lowering the selling price. This article provides strategies to improve the quality of the fisheries sector through port governance system with cooperation scenarios. The main idea is general ports and national fisheries companies has a joint cooperation to build and operate cold storage facilities in the general ports area (case study at Port of Tegal). In the planning process, the general port companies invest cold storage building and machinery, while the fishing companies operate cold storage facilities. In order to know the quantitative effects of scenarios, the financial approach with NPV, and IRR components is conducted in this article. The result shows that this scenario gives IRR approximately $20 \%$ $50 \%$ for overall network. The proposed scenario is expected to provide information to various groups (such as government, decision maker, general ports companies, fishing companies, and fishermen) that integrated between general port and fish operator may give a better impact the future fishing sector especially in national fishing logistics.
\end{abstract}

\section{Introduction}

Within a few years, the development of Indonesian fishery sector showed a significant increase. In 2015, Indonesia fishery production reached 22 million tons, compared to 2010 at 11 million tons [1]. Furthermore, Indonesian fishery from year to year has increased. In the period of 2010-2015, the increase of Indonesian fishery production is an average of $1.1 \%$ per year. 
Good management and law enforcement is considered as the main reason of the positive impact on Indonesian fishery production. This can be seen by seeing the development of fishery production not only lies in the production of capture fisheries, but also on the production of aquaculture fishery [2]. Capture fisheries production currently stands at 6.6 million tons in 2015 , up $1.2 \%$ from a year earlier. In the aquaculture production sector actually exceeds the production of capture fisheries. By 2015, aquaculture production reached 16.6 million tons, and increased 1.09\% from a year earlier [1].

In maintaining fishery securities and sustainability, increased fisheries production should be strengthened by improved quality of post-catchment handling [3] [4] [5]. Food losses due to destruction of fishery products are the main reason for quality improvement [6] [7]. FAO further explained basically humans prefer fresh fish compared to fish in the form of processed. Therefore, fish handling technology began to grow to keep the quality of fishery products from post-catch to the consumer [8].

One method of maintaining the quality of fishery products is by cold chain management [9]. Through the cooling process, cold chain method can keep the fishery product from the process of decomposition. Cold chain management requires a facility called cold storage facility. In cold storage, there is cleaning, freezing and storage. With this function, cold storage is not only able to maintain quality as a product delivery facility, but also keep the fish supply during the low season catch.

In the process of applying cold chain management, there are several obstacles that may occur and disrupt the stability of supply. Facilities limitations, engine breakdowns, handling errors, and oversupply are among the many constraints faced in maintaining product quality. Other constraints that may occur there is from the process of shipping fisheries products from cold storage to consumers (transportation) [6].

In general, cold chain facilities are in a different area than the product delivery port. Cold storage facilities tend to be in the fishing ports, and the product port delivery facilities are in general ports [10]. The constraints faced by this separate system are the process of developing longer facilities, and requiring more land. Separation of facilities also makes the series of shipping fishery products longer. The separation of these two facilities is due to different management. Fishery facilities are under the fishery industry, while general port facilities are managed by the port company [11].

In terms of planning and development, a separate supply system has several disadvantage. Especially in inefficiency in capital cost, and the duration of supply. With a separate supply, the cost that must be incurred by stakeholders is the cost of dock construction and supporting facilities for fishing port and public port. Disadvantages in supply duration are related to the length of the process in which one step will accumulate. Therefore, cutting the stages will save the cost of dock construction and reduce the supply duration.

In this article, collaborations between the fish operator and port companies are proposed as new opportunities in the future as the development of fisheries and general industry management. The main idea of this strategy is the joint development and operation of cold storage facilities at general ports. With this idea is expected to process the development of fisheries facilities and general ports can be more quickly, efficiently, and integrated. The purpose of this article is to provide an overview of the integration between general ports and fisheries companies for possible future cooperation.

\section{Integrated Management of Port}

Integrated management of coastal zones is planning and coordination related to the development of port and resource management that focuses on coastal and marine areas. This method was introduced in 1988 by Chua Thia-Eng to collect activities related to coastal and aquatic areas in one central place. Integration will provide benefits in terms of (1) cost reduction and delay on development implementation, (2) minimize damage to the environment and water resources, (3) 
reduce the amount of land used, (4) provide development efficiency and infrastructure operations [12].

In running integrated management of coastal zones, several aspects need to be considered. Legal commitment is a key foundation in planning to support resource and environmental management. Assessing and understanding the resource data contained in an area is also required for the development process. And the inter-agency coordination aspect is needed so that every development in every field can run well [12].

In Indonesia the integration of ports has been a lot of port references to improve operating efficiency. The elements currently integrated are ports, industrial estates, distribution, and warehousing. In its pattern of operation, the port serves as a logistic gate. Industrial area serves as a center of business activity. The distribution aspect is intended as a forwarding services management for the distribution of further loads. While warehousing serves to provide a buffer zone as a temporary storage. This circulation then continues to be interconnected and provides benefits to each sector [13].

Such a pattern of work is required to be applied in the fisheries sector. Integration between public and fishery ports is an important thing to do considering that cold storage needs are always directly proportional to production and export flow. The integration of general ports and fisheries will also make port development faster, better management, reduce environmental damage, and land use. Integration will also make the process of shipping fish using the ship becomes easier because it is located in the port area.

\section{Port Integration on Fishing Cold Chain Management}

Integration of fishery and general ports is motivated by current separately management of facilities between general ports and fishing ports. The disadvantages of port separation can occur in several stages related to the planning, development and operation process. In this management system, one city may have two ports with different functions. It is using more area, and the construction of two ports separately in one city will also lead to a longer distribution of fisheries market. Figure 1 shows the general concept of port integration.

Port integration on cold chain fishing is a method that we offer as an effort to increase fisheries development through collaboration between general port and fish operator. The main idea is that general ports and fish operator establish and operate cold chain facilities in general port areas within the scope of cooperation. With the integration, process of catching, cooling, storage, and shipping fish products may to be shorter. Since the part of the supply chain process is done in one place.

Figure 2 shows the cold chain management process before port integration. Fishing vessels arriving at fishing port will be handled by fish operator. Then the fish operator processes the fish products for sale directly or through the process of freezing. Frozen fish products will be distributed by land and sea after packing process. For products shipped by vessel, fisher operator or other companies will bring frozen fish product to general port. The general port will process the product through the stuffing (loading product into container), stacking, and the container will wait until the vessel arrives at the port.

With the integration of the port, the procedure shown in Figure 2 can be reduced as shown in Figure 3. With the integration, fishing vessels that arrive at the port will be handled by general port and fish operator. Fish operator will process, freeze, store, and pack the product. While the general port will handle the process that related to ships, and the process of delivery of goods by sea. 


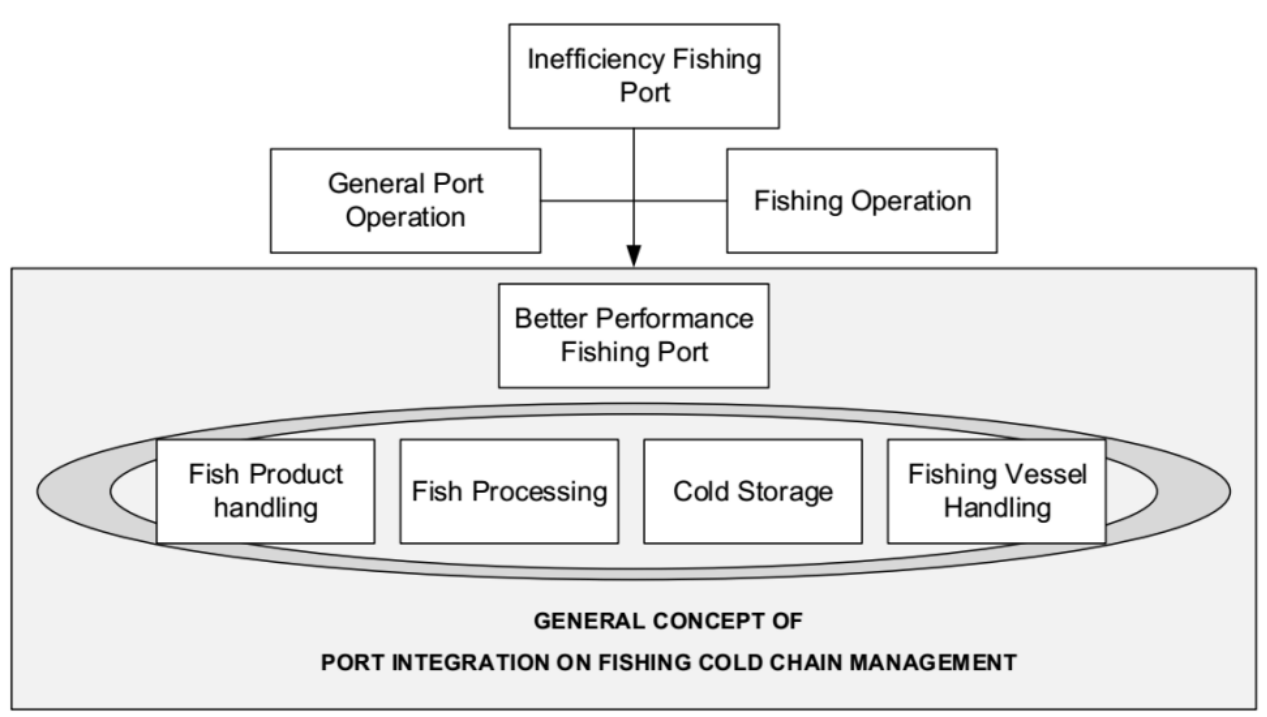

Figure 1. General concept of integration on fishing cold chain management.

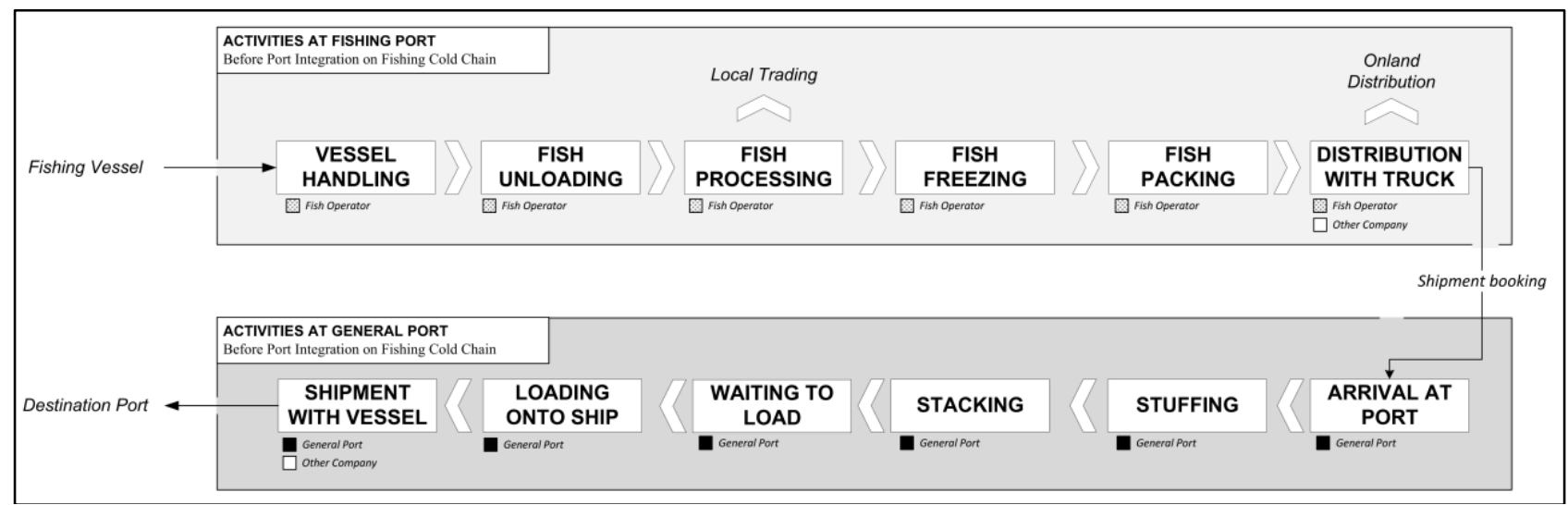

Figure 2. Activities at fishing port: before port integration on fishing cold chain.

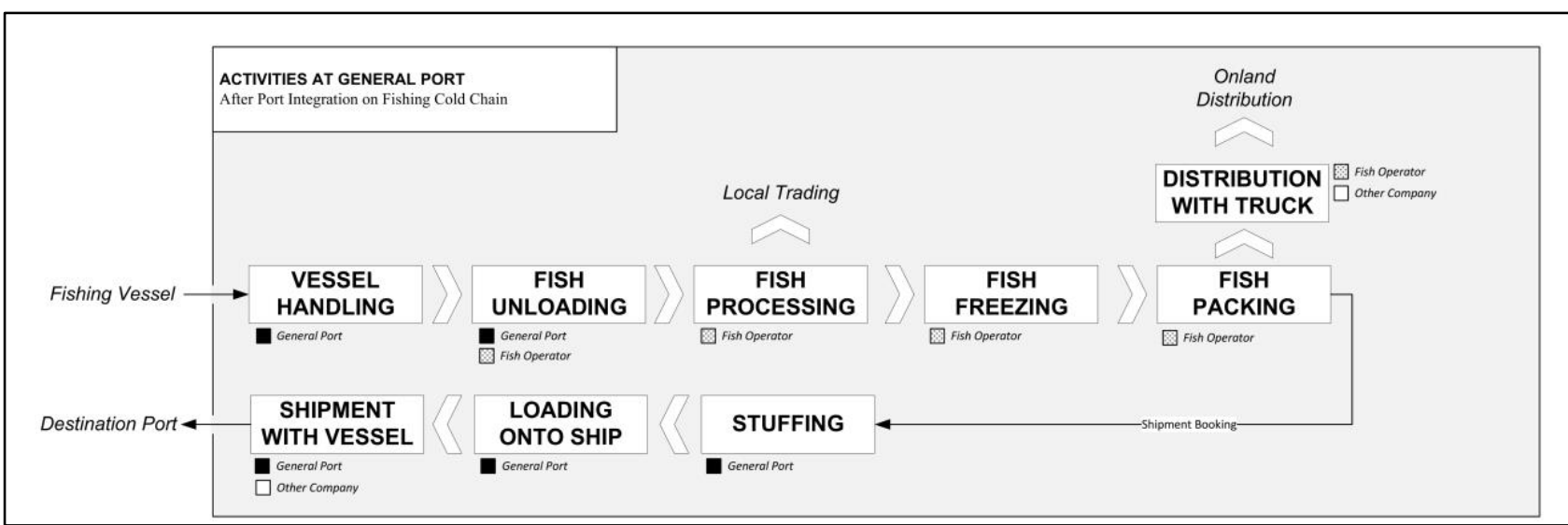

Figure 3. Activities at general port: after port integration on fishing cold chain.

With the integration of ports and the improvement of integrated information systems, the procedure for ship transport of products can be minimized since the product stuffing process to the containers can be customized with ship arrival information.

Port integration on cold chain management is planned by collecting some cold chain elements. The elements consist of fish product handling, fish processing, cold storage, fish product shipping, and fishing vessel handling. Each function of one element will support each other's function. 
Fish product handling - fish product handling is a function of handling fresh fish when fishing boats arrive. Fish products that have been captured will be derived, classified, and reported. After the data collection process, fish products will be passed to the fish processing stage.

Fish processing - fish processing is a fish processing activity to be cleaned, and in the fillet (if necessary) before the freeze. Fish processing is done in cold storage. Machinery, and water used are facilities that have been provided in cold storage

Cold Storage - cold storage is divided into two sub-systems. That is freezing, and storage. Freezing serves to lower the temperature (up to $-25^{\circ} \mathrm{C}$ ). The freezing process is intended to prevent bacteria from killing and preventing decay. The second sub-system is a storage facility. Frozen fish are then stored in cold storage until the product is sold.

Fish product shipping - frozen fish that has been stored in the shipping process is done. Delivery by truck can be directly transferred from cold storage. While ship shipments, the process of moving fish is done as a fish product handling process.

Fishing vessel handling - in addition to fishery trade process, fishing boats can also access the accommodation facilities that have been provided port. Fishermen can refuel, water and supplies before sailing.

Given the method of port integration, the common port will benefit from an increase in the number of voyages. For the fish operator, port integration will facilitate the development of facilities, and reduced transportation costs. While fishermen also benefit because their fishery products can be directly marketed.

\section{Integrated Cold Storage Investment \& Operation}

Port integration on cold chain management will be managed jointly by general ports and fish operator. General ports will still have their basic duties as they are. Fish product handling, fish product shipping, and fishing vessel handling will be part of common port duties. The cooperation between general ports and fisheries companies lies in the construction and operation of cold storage.

General ports have a part to invest in cold storage facilities that do not move. These facilities are cold storage, insulation, machinery, control and maintenance. The investment of immaculate cold storage facilities will facilitate the design, arrangement, fabrication and maintenance of facilities. This relates to the development site located in the area of the general port itself.

The fish operator has a part to invest to operate cold storage facilities, and runs cold storage businesses. The facilities invested consist of forklifts, racks, and other necessities. The fish operator also has a section to run cold storage businesses ranging from fish processing, freezing, fish storage, and selling of frozen fish products. The fish operator will be charged for the rental of the building and its permeability system.

Design stage - Collaboration between general port and fish operator starting from the cold storage capacity design stage. The joint capacity determination aims to adjust some issues related to fisheries production, the availability of land in ports, the rental price charged, and the pattern of operations. At this stage the general ports and the fish operator will have a collective agreement in the initial process of integration.

Manufacturing Stage - At the manufacturing stage, the general port and the fish operator begin investing in accordance with their respective sections. During this stage, both the general port and the fish operator closely monitor the manufacturing process.

Operation phase - At the operational stage, the fish operator is responsible for running a cold storage business, gaining operating profit, and contributing to a commonly establish.

Port integration can be started from the beginning of design, manufacture, until the operation. Table 1 presents a scenario of cooperation between general port and fish operators. At the planning stage, 
general port and fisher operator undertake the joint agreements relating to cold storage capacity, throughput that fish operator can meet, and design planning by general ports. At the development stage, the general port will invest in construction, quarrying, electricity, automation systems, and generators. While fish operator invests in fishing gear (forklift, and fish rack). At the operational stage, the fish operator run the cold storage business, while the general port will be responsible for investing cold storage facility.

Figure 4 shows the investment scenario and cold storage operations between general port and fish operator. The general port will provide the area in the port to be built a cold storage facility and can be operated without inhibits the port activities. After the cold storage facility is built, the fish operator will operate it. Fish operators may have benefit from cold storage operations, and are obliged and contribute in the form of rental buildings, and machinery to the general port.

Table 1. Scenario of joint coorporation between general port and fish operator.

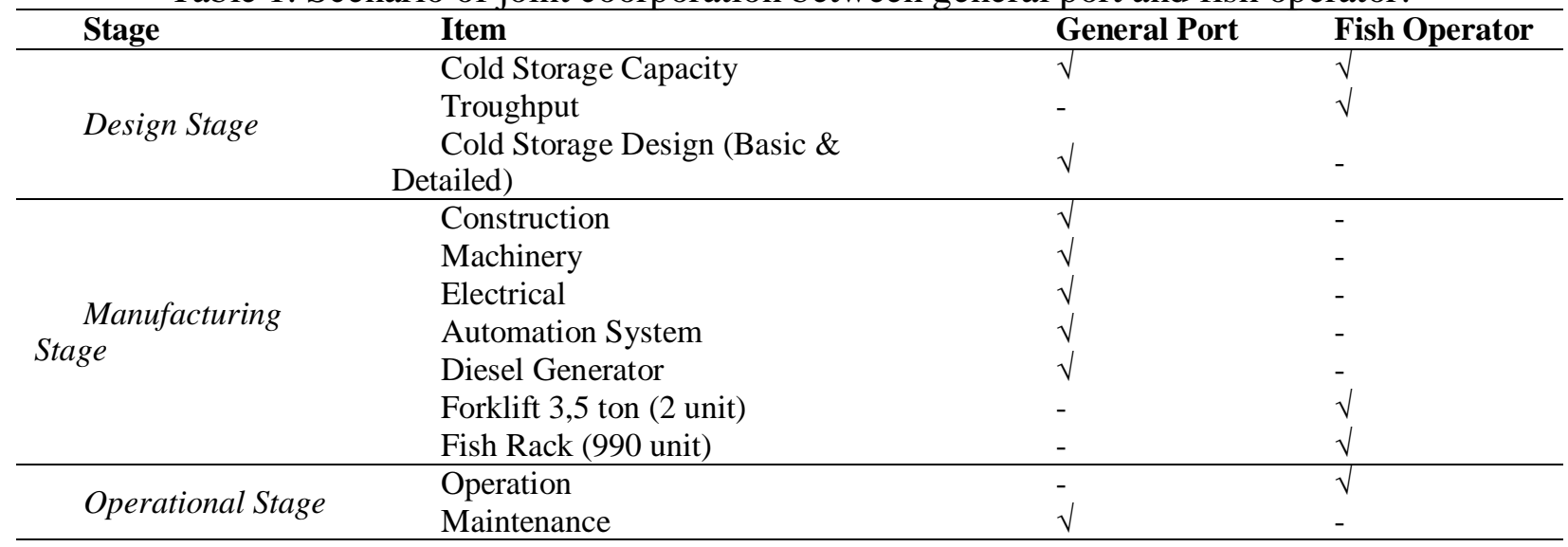

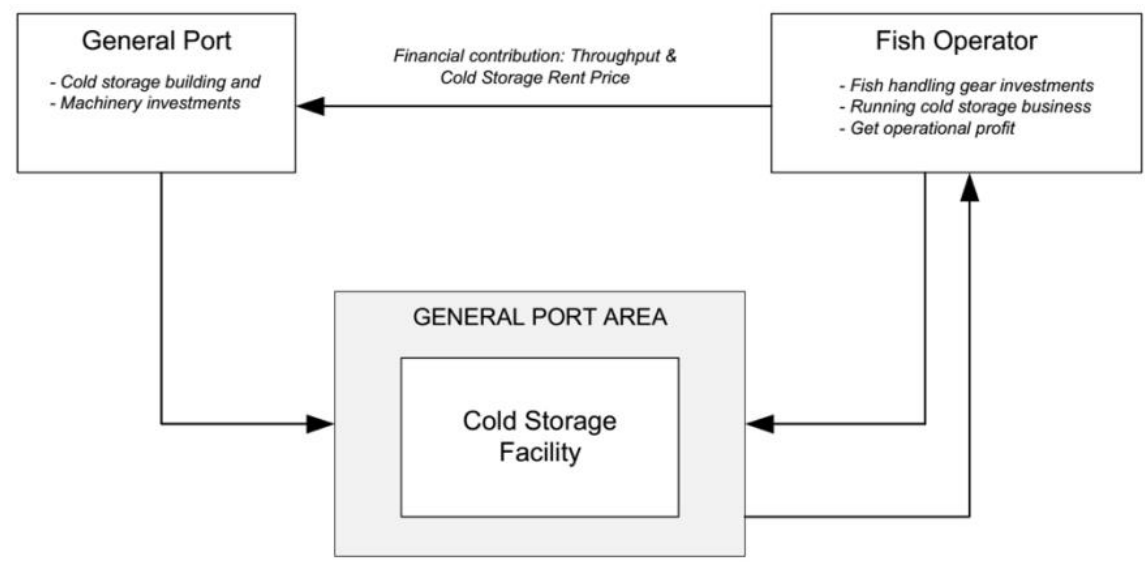

Figure 4. Scenario of investment and operation between general port and fish operator.

\section{Financial Approach}

Financial analysis in this feasibility study aims to provide an overview of the potential outcomes, revenues and costs for stakeholders in the development of integration port on cold chain management. The port area that will be used as a case study is a general port area of Tegal. The approach of financial analysis is done by using Discounted Cash Flow (DCF), which takes into account the value of the investment based on the discount from the net cash flows of an investment.

As mentioned earlier, the general ports are investing in the initial construction of a cold storage facility, while the fish operator invests forklifts and tiger cage purchases and operates by providing a share of operating income in the form of rental of warehouses and contributions to general ports. 
In the financial analysis required the existence of financial assumptions related factors external factors that can affect the results of financial analysis. The table displays the specifications used in the case study of the Tegal city port area.

\subsection{Market Opportunity}

Tegal is a coastal city located in the province of central java. Tegal city with $3.850 \mathrm{Ha}$, bordering with Brebes in the West, Java Sea in the North, and Tegal Regency in the East and the South. Tegal city is located in $165 \mathrm{~km}$ west of Semarang, and $329 \mathrm{~km}$ east of Jakarta. Tegal city is strategically positioned on the Java North Coast line connecting major cities in the northern of Java.

Tegal consists of one general port known as the Tegal general port (Pelabuhan umum tegal), and a fishing port named Tegalsari fishery port. The general port is managed by PT. Pelabuhan Indonesia III, while Tegalsari port is managed by the Ministry of Fisheries.

Based on data from Indonesian Central Bureau of Statistics (Badan Pusat Statistik) (2015), the average capture fisheries production from 2010 to 2015 reached 69.522 tons per year. The production is served by 11 units of cold storage with a total capacity of 1.245 tons ( 39.840 tons per year) which has been available in Tegalsari port. From the total production not all can be stored in the existing facilities. As an impact, some fish production is preserved with salted. The process of salting the fish causing on the lower fish prices.

Figure 5 shows the percentage of fisheries that can be taken as a market opportunity and to be stored in cold storage facilities that have been integrated with the general ports. The amount of market opportunity that can be taken is 29.682 tons. The value will be the basis of cold storage facility planning. Since cold storage capacity will be below market opportunities.

The average potential of fishery production of Tegal city per year in Total $69.522 .000 \mathrm{~kg}(2010-2015)$

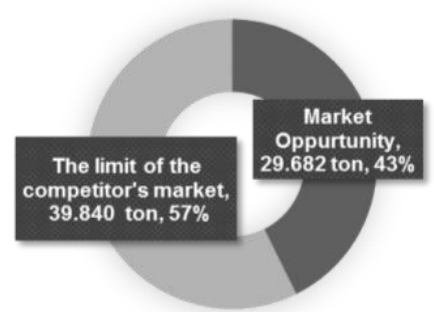

Figure 5. Market oppurtunity of fish production in Tegal City.

\subsection{Cold Storage Specification}

From the market opportunity shown in Figure 5, the cold storage capacity will not exceed 29.682 tons per year. Therefore, cold storage for fisheries is designed with 850 tons, capacity. If it is operated in a weekly cycle for 32 weeks, then the fish that can be stored is 27.200 tons per year. In addition, for saving capture fisheries, cold storage will also provide another storage for products other than fish for 170 tons. This facility can be used for local to store their food products. Cold storage will also be equipped with a cooling machine type air blasting freezer with 2 x 6 tons capacity that can freeze the product within 6 hours.

Figure 6 shows the basic design of cold storage to be built at the Port of Public. 


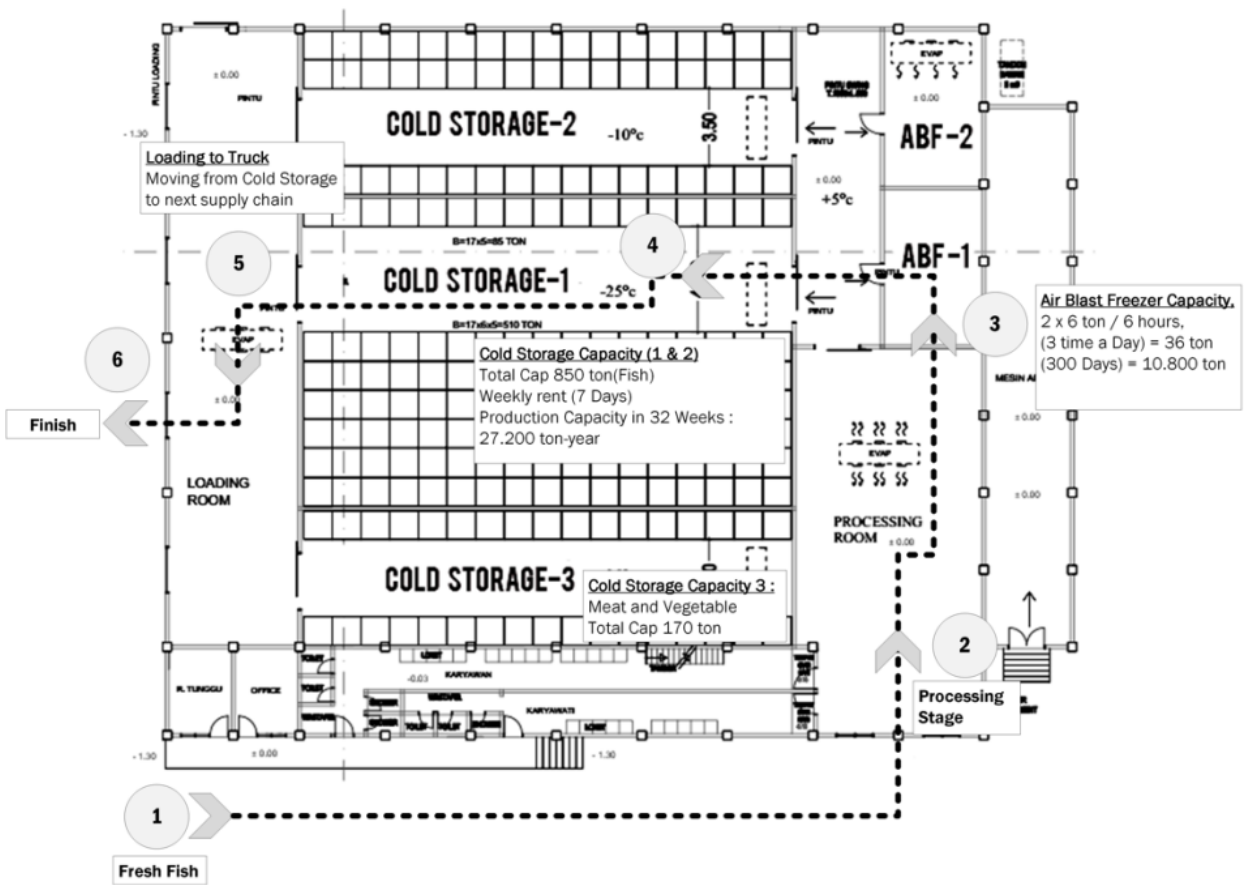

Figure 6. Basic design of cold storage in general port area.

Table 2 shows the detail capacity of cold storage. Cold storage facility consists of 3 units of cold storage room, and 2 units of freezer. A, B, and C cooling rooms with a capacity of 255 tons, 595 tons, and 170 tons respectively. Cold room $\mathrm{C}$ is only used for products other than fish.

Table 2. Cold storage and freezer capacity.

\begin{tabular}{llll}
\hline $\boldsymbol{N o}$ & Unit & Space capacity & One year production capacity \\
\hline 1 & Cold Storage & & \\
& - Cold Room A & 255 ton & 8,160 ton (32 weeks) \\
& - Cold Room B & 595 ton & 19,040 ton (32 weeks) \\
& - Cold Room C & 170 ton & 5,440 ton (32 weeks) \\
& & & \\
& & 2 unit x 6 ton / 6 hour & 10,800 ton (300 days) \\
& Air blasting freezer & & \\
& & &
\end{tabular}

\subsection{Investment}

The cold storage facility investment scenario is based on Table 1 . The general port invests for construction, machineries, electrical, automation, and electric diesel generator. While the fish operator invests in the procurement of forklift and fish rack. Figure 5 shows the percentage of investment between general ports and fish operator. General port invests $88 \%$, with a total of 24.69 billion rupiahs. The fish operator invests $12 \%$ or equivalent to 3.39 billion rupiahs.

Tables 3 and 4 show details of each investment issued by general ports and fish operator. Table 3 shows that construction and machinery dominate common port investment. 


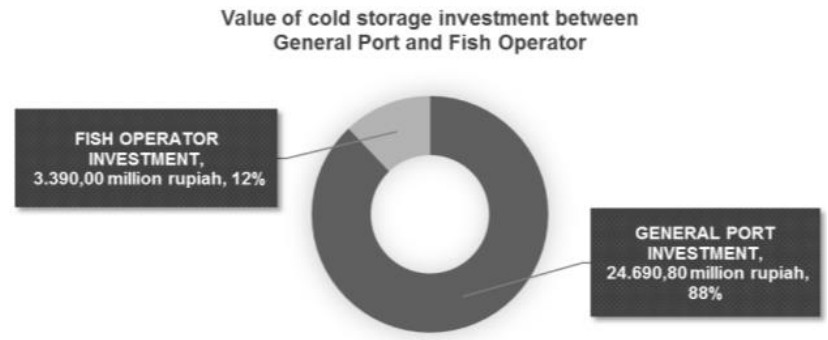

Figure 7. Cold storage investment comparison between general port and fish operator.

Table 3. General port investment for cold storage facility.

\begin{tabular}{lr}
\hline Item of Investment & Price (in million rupiah) \\
\hline Construction & $10.089,5$ \\
Machinery & $10.175,0$ \\
Electrical & $1.500,0$ \\
Automation System & 926,4 \\
Diesel Generator & $2.000,0$ \\
\hline Total & $\mathbf{2 4 . 6 9 0 , 8}$ \\
\hline
\end{tabular}

Table 4. Fish operator investment for cold storage facility.

\begin{tabular}{lr}
\hline Item of Investment & Price (in million rupiah) \\
\hline Forklift 3,5 ton ( 2 unit) & $2.400,0$ \\
Fish Rack (990 unit) & 990,0 \\
\hline Total & $\mathbf{3 . 3 9 0 , 0}$ \\
\hline
\end{tabular}

Table 4 shows that the dominant investment by fish operator is the purchase of forklifts. The main reason for purchasing forklifts and fish racks is charged to fish operator is that their users are heavily dependent on operators' operational expertise.

\subsection{Operational Cost}

To operate a cold storage facility some values will be set as part of a financial approach. Table 5 shows some of the values agreed by general ports and fish operator. This value is used when conducting a financial approach consisting of WACC, inflation, taxes, economic age, to rental rates. The value of cold storage rental, and ABF by consumers for fish operator is 300 rupiah / $\mathrm{kg} /$ week and 1,500 rupiah / $\mathrm{kg} /$ process. While the value of cold storage rental, and ABF by fisheries operator for general port is 20 rupiah / $\mathrm{kg} /$ week and 1,000 rupiah / $\mathrm{kg} /$ process. The values shown in Table 5 may be different for the case, or a different pattern of cooperation in accordance with the agreement.

Table 5. Several value on financial approach of cold storage operation.

\begin{tabular}{|c|c|c|c|c|}
\hline No & Item & Value & & Unit \\
\hline 1 & Wacc & & $13,92 \%$ & \\
\hline 2 & Inflation & & $3 \%$ & \\
\hline 3 & Tax & & $25 \%$ & \\
\hline 4 & Life-time & & 10 & Years \\
\hline 5 & Electrical standard price & $\mathbf{R p}$ & 1.460 & $/ \mathrm{KWH}$ \\
\hline 6 & Fresh water price & $\mathbf{R p}$ & 12 & $/$ Ltr \\
\hline 7 & Staff minimum wage & Rp & 1.400 .000 & \\
\hline 8 & Consumer cold storage rent price & $\mathbf{R p}$ & 300 & $/ \mathrm{Kg} /$ week \\
\hline 9 & Consumer ABF rent price & $\mathbf{R p}$ & 1.500 & $/ \mathrm{kg} /$ process \\
\hline 10 & $\begin{array}{l}\text { Fish operator cold storage contribution } \\
\text { price }\end{array}$ & $\mathbf{R p}$ & 20 & $/ \mathrm{kg} /$ week \\
\hline 11 & Fish operator freezer contribution price & $\mathbf{R p}$ & 1.000 & $/ \mathrm{kg} /$ process \\
\hline
\end{tabular}




\subsection{Cashflow Result}

Figure 8 shows the annual cash flow from cold storage operations with a duration of 230 days per year. In year 0 , expenditure is focused on cold storage investment. General ports and fishing operators do their share in investment. Cold storage operations start from year 1 to year 10 . In year $1-4$, cold storage operating income is still not maximized, this is due to the adjustment of new facilities to its market share. In the 5th - 10th year, cold storage operations are operating maximally.

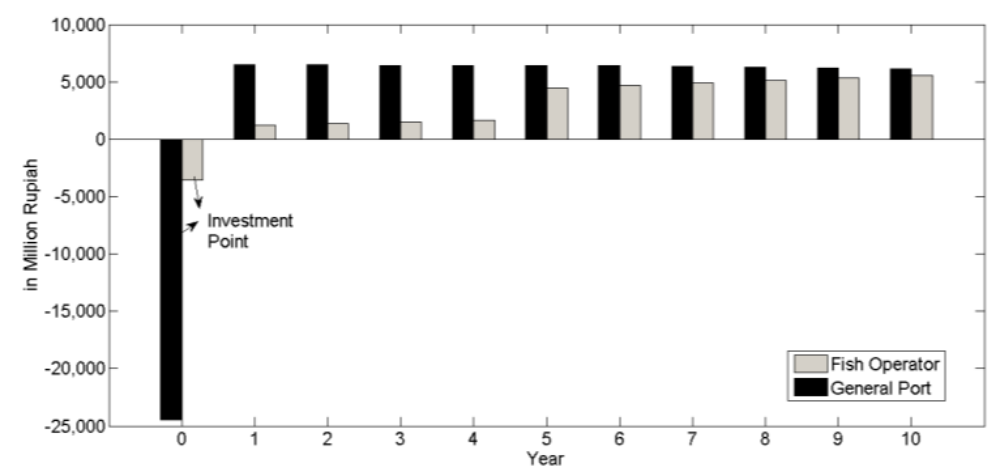

Figure 8. Cash flow data from cold storage operation between general port and fish operator.

\subsection{Cashflow Accumulation Result}

Figure 9 shows the accumulated cash flow from cold storage operations consisting of revenues and expenses. Revenue received by fish operators and general ports periodically eliminates the investments that have been issued. The accumulation of general port revenue and fishery operators may exceed the value of investments incurred in year 4 . The accumulated cash flows in the 10th year between general ports and fish operator are 39.13 billion rupiah and 32.09 billion rupiah.

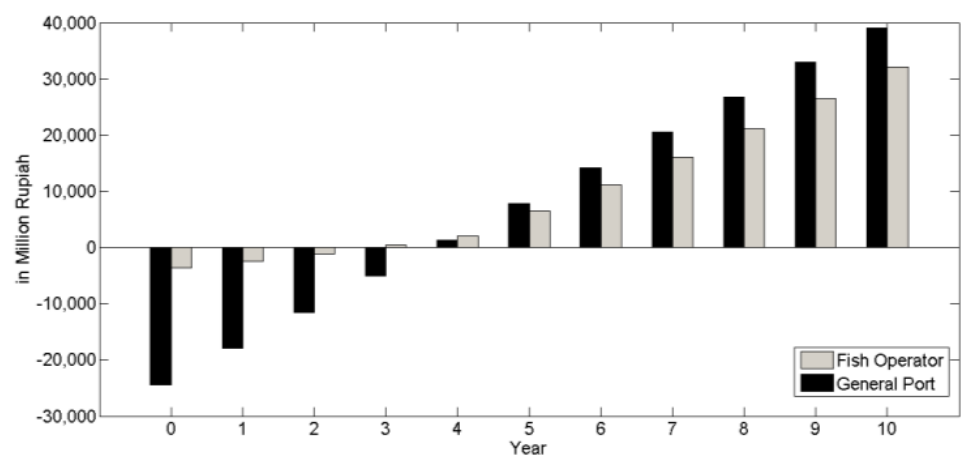

Figure 9. Cash flow accumulation data from cold storage operation between general port and fish operator.

From the accumulated cash flow, and considering the weighted average cost of capital (WACC), the value of present net value from cold storage operation can be known. Table 6 presents the results of the financial approach of operating cold storage. In the Port of General's financial approach, from an investment of 24.69 billion rupiahs, the NPV earned is 8.98 billion rupiah or the amount of the Index Rate of Return equals $22.85 \%$, and the payback period at 3.8 years or in the 4 th year In the fisheries operator finance approach, from 3.39 billion investment, the NPV obtained is 11.84 billion rupiah or the amount of Index Rate of Return is equal to $52.76 \%$ and the payback period is 2.72 years or in the 3rd year. 


\section{Conclusion}

In this article we offer the idea of port integration on cold chain fishing management to collaborate between general ports and fish operator. Integration consists of joint management of fishery facilities at general ports. The general ports have parts to build cold storage and machining buildings, and fisheries companies are responsible for the operation and investment of cold storage mobile facilities. With this method, the supply chain of fisheries can be reduced so as to reduce the operational costs of the fishery sector. The advantages that are also provided with the method of integration of public and fishery ports are improving product quality, increasing the activities of general ports and fisheries, reducing the land used, and developing ports more quickly. With case studies of the city of Tegal, it appears that joint management can provide benefits for all parties, especially general ports and fisheries companies. The proposed scenario is expected to provide information to various groups (such as government, decision maker, general ports companies, fishing companies, and fishermen) that integrated between general port and fish operator may give a better impact the future fishing sector especially in national fishing logistics.

\section{References}

[1] BPS-Statistics Indonesia, "Fish Production by Subsector," 2016. [Online]. Available: https://www.bps.go.id/statictable/2014/01/16/1711/produksi-perikanan-menurut-subsektor-ribu-ton-19992015.html. [Accessed 20 December 2017].

[2] Suhana, Kebijakan kelautan dan perikanan dan implikasinya terhadap kelestarian sumberdaya ikan dan ekonomi perikanan Indonesia, 2015, pp. 70-76.

[3] J. D. Bell, M. Kronen, A. Vunisea, W. J. Nash, G. Keeble, A. Demmke, S. Pontifex and S. Andréfouëtc, "Planning the use of fish for food security in the Pacific," Marine Policy, vol. 33, no. 1, pp. 64-76, 2009.

[4] R. B.-. Melis, U. Mc Carthy, L. R.-. Garcia, J. G.-. Hierro and J. R. Villalba, "New trends in cold chain monitoring applications - A review," Food Control, vol. 86, pp. 170-182, 2017.

[5] A. Cahaya, "Fishermen community in the coastal area: a note from indonesian poor family," Procedia Economics and Finance, vol. 26, pp. 29-33, 2015.

[6] H. Huss, Quality and quality changes in fresh fish, Rome: Food and Agriculture Organization, 1995.

[7] S. Hughes, A. Yau, L. Max, N. Petrovic, F. Devenport, M. Marshall, T. R. McClanahan, E. H. Allison and J. E. Cinner, "A framework to assess national level vulnerability from the perspective of food security: The case of coral reef fisheries," SciVerse Sciendirect, vol. 23, pp. 95-108, August 2012.

[8] FAO, Freezing and refrigerated storage in fisheries, Scotland: Food and Agriculture Organization of The United Nation, 1994.

[9] H. Bremmer, Safety and Quality Issues in Fish Processing, North America: CLC Press, 2002.

[10] V. Hongskul, Into the Next Millennium: Fishery Perspective, Bangkok: Food and Agriculture Organization of the United Nations, 1999.

[11] Kementerian Kelautan dan Perikanan, Membangun Kedaulatan Perikanan melalui Pemberantasan Illegal Fishing, Jakarta, 2016.

[12] A. Sarker, T. Abe, T. Ikeda and K. Inoue, "Design principle for managing coastal fisheries commons in presentday Japan," vol. 117, no. Ecological Economics, 2015.

[13] U. R. Sumaila, C. Bellman and A. Tipping, "Fishing for the future: An overview of challenges and opportunities," Marine Policy, vol. 69, pp. 173-180, 2016. 